\title{
Convergence of Evidence Supports a Chuska Mountains Origin for the Plaza Tree of Pueblo Bonito, Chaco Canyon
}

\author{
Christopher H. Guiterman (D, Christopher H. Baisan, Nathan B. English, Jay Quade, Jeffrey S. Dean, \\ and Thomas W. Swetnam
}

\begin{abstract}
The iconic Plaza Tree of Pueblo Bonito is widely believed to have been a majestic pine standing in the west courtyard of the monumental great house during the peak of the Chaco Phenomenon (AD 850-1140). The ponderosa pine (Pinus ponderosa) log was discovered in 1924, and since then, it has been included in "birth" and "life" narratives of Pueblo Bonito, although these ideas have not been rigorously tested. We evaluate three potential growth origins of the tree (JPB-99): Pueblo Bonito, Chaco Canyon, or a distant mountain range. Based on converging lines of evidence-documentary records, strontium isotopes $\left({ }^{87} \mathrm{Sr} /{ }^{86} \mathrm{Sr}\right)$, and tree-ring provenance testing-we present a new origin for the Plaza Tree. It did not grow in Pueblo Bonito or even nearby in Chaco Canyon. Rather, JPB-99 originated from the Chuska Mountains, over 50 km west of Chaco Canyon. The tree was likely carried to Pueblo Bonito sometime between $A D 1100$ and 1130, although why it was left in the west courtyard, what it meant, and how it might have been used remain mysteries. The origin of the Plaza Tree of Pueblo Bonito underscores deep cultural and material ties between the Chaco Canyon great houses and the Chuska landscape.
\end{abstract}

Keywords: ancestral Puebloan, Chaco Canyon, tree rings, strontium isotopes, Neil Judd, Andrew Ellicott Douglass, timber origins, human-environmental interactions, archaeology, Chuska Mountains

Se cree que el emblemático árbol de la Plaza de Pueblo Bonito fue un majestuoso pino que se encontraba en el patio oeste de la gran casa monumental durante el auge máximo del Fenómeno del Chaco (850-1140 dC). El tronco de pino ponderosa (Pinus ponderosa) fue descubierto en 1924, y desde entonces ha sido incluido en las narraciones de "nacimiento" y "vida" de Pueblo Bonito, aunque estas ideas no han sido rigurosamente probadas. Evaluamos tres posibles orígenes de crecimiento del árbol (JPB99): Pueblo Bonito, Chaco Canyon, o una cordillera distante. Basado en líneas de evidencia convergentes-registros documentales, isótopos de estroncio $\left({ }^{87} \mathrm{Sr} /{ }^{86} \mathrm{Sr}\right)$, y pruebas de procedencia de anillos de árboles-presentamos un nuevo origen para el Árbol de Plaza. No creció en Pueblo Bonito o incluso en el cercano Cañón del Chaco. Más bien, JPB-99 creció en las montañas Chuska, a más de $50 \mathrm{~km}$ al oeste del Cañón del Chaco. El árbol probablemente fue llevado a Pueblo Bonito en algún momento entre 1100 y $1130 \mathrm{dC}$, aunque por qué se dejó en el patio oeste, su significado, y cómo podría haber sido utilizado siguen siendo misterios. El origen del Árbol de la Plaza de Pueblo Bonito subraya los profundos lazos culturales y materiales entre las grandes casas del Cañón del Chaco y el paisaje de Chuska.

Palabras clave: Puebloan ancestral, Chaco Canyon, el toques de árboles, isótopos estroncio, Neil Judd, Andrew Ellicott Douglass, orígenes de la madera, interacción humano-ambiente, arqueología, Las Montañas Chuska

$\mathrm{T}$ The Plaza Tree of Pueblo Bonito is one of the most iconic individual trees in the archaeology of North America. The tree, a ponderosa pine (Pinus ponderosa), is known variously as the "tree of life," "world tree," "rooted tree," and the "lonesome pine." It is

Christopher H. Guiterman (chguiterman@email.arizona.edu, corresponding author), Christopher H. Baisan, Jeffrey S. Dean, and Thomas W. Swetnam a Laboratory of Tree-Ring Research, University of Arizona, 1215 E Lowell St. Box 210045, Tucson, AZ 85721, USA

Nathan B. English $\square$ School of Health, Medical and Applied Sciences, Central Queensland University, Townsville, QLD 4810, Australia

Jay Quade - Department of Geosciences, University of Arizona, Tucson, AZ 85721, USA

American Antiquity 85(2), 2020, pp. 331-346

Copyright (C) 2020 by the Society for American Archaeology. This is an Open Access article, distributed under the terms of the Creative Commons Attribution licence (http://creativecommons.org/licenses/by/4.0/), which permits unrestricted re-use, distribution, and reproduction in any medium, provided the original work is properly cited.

doi:10.1017/aaq.2020.6 
depicted by the National Park Service as a majestic lone pine standing in the west plaza of Pueblo Bonito, Chaco Canyon, in northwest New Mexico, USA, during its peak occupation in the late eleventh century (Figure 1). A $6 \mathrm{~m}$ long segment of the tree's trunk, with some primary roots attached, was discovered in an excavation trench through the west plaza during the 1924 National Geographic excavation, led by Neil Judd of the Smithsonian Institution (Figure 2). For decades after its discovery, the tree was only known to a handful of archaeologists and researchers. The mystery and mythological nature of the tree arose in the 1950s with Judd's emphatic description:

\section{At the south end of the West Court we unex- pectedly discovered the remains of a large pine that had stood there, alive and green, when Pueblo Bonito was inhabited. Its decayed trunk lay on the last utilized pave- ment, and its great, snaglike roots preclude the possibility of its ever having been moved [Judd 1954:3].}

This is the origin narrative of the Plaza Tree. Judd describes the tree as lying on the last occupation surface of the west plaza in Pueblo Bonito, having large attached roots, and he asserts the impossibility of it being moved to that location from somewhere else by people. Judd (1954) viewed the tree as a relic of an expansive ponderosa pine-dominated forest in Chaco Canyon that was harvested to build the great houses. From there, the tree has taken on a new life in the archaeological literature and National Park Service interpretations. For example, it is considered by some (e.g., Ashmore 2007; Stein et al. 1997) as vital to the site location, design, and existence of Pueblo Bonito. Judd's narrative and the broader interpretive symbology of the tree, along with the grandeur of a stately pine in a monumental great house as portrayed by the National Park Service (Figure 1), have persisted without scrutiny for decades. But recent inquiries by us and another researcher (Wills 2012) may change the way we think about the Plaza Tree of Pueblo Bonito.

As he did with most of the wood he recovered from archaeological sites, Judd sent a sample of the tree to Andrew Ellicott Douglass at the
University of Arizona. This was during the early days of dendrochronology, and Douglass - who designated the tree as JPB-99, or "Judd Pueblo Bonito number 99"- - was able to crossmatch (i.e., "cross-date") its ring-width pattern to other archaeological specimens from Chaco Canyon and elsewhere in the region (Douglass 1935). The tree has since been examined by several other dendrochronologists (Bannister 1977; Robinson et al. 1974), including by three of the authors, to confirm that JPB-99 dates to AD 732-981 + vv. The outermost ring on the specimen dates to exactly 981 ; the "+vv" symbol indicates that we cannot know the true year in which the tree died (or was cut) because of substantial wood loss over time from decay and erosion. Its current outermost ring probably lies at or near the boundary of the resin-infused and decayresistant heartwood and the decay-prone sapwood portion of the tree trunk that was lost to time.

The Plaza Tree's symbolic standing as a remnant of a prehistoric Chaco forest was reinforced by Judd's visits to several scattered ponderosa pine trees and deadfall logs in the canyon (Judd 1954, 1964). Judd made these visits with Navajo guides, who might have described to him the namesake for Gallo Canyon, which extends north not far from Pueblo Bonito, as Ńdíshchíí' Haazt' $i$ ' - the Diné term for "pine trees extend up in a slender line." Today, ponderosa pines are rare inside and near Chaco Canyon. Paleoenvironmental reconstructions show that the situation was not much different during the Chaco era. There were not enough ponderosa pines or other conifer trees in the canyon to support timber demand (Betancourt and Van Devender 1981; Hall 1988). The primary sources for construction timbers, especially ponderosa pines, were the Zuni Mountains and Chuska Mountains, each more than $50 \mathrm{~km}$ away (English et al. 2001; Guiterman et al. 2016; Reynolds et al. 2005). These findings pose a challenge to Judd's interpretation of the Plaza Tree as having grown in situ. In fact, it could have been moved to that location-most likely as a dead tree with some cut-off roots attached-given that hundreds of thousands of timbers, many of which were relatively large and unwieldy, were handcarried over great distances across the high desert to Chaco Canyon. 


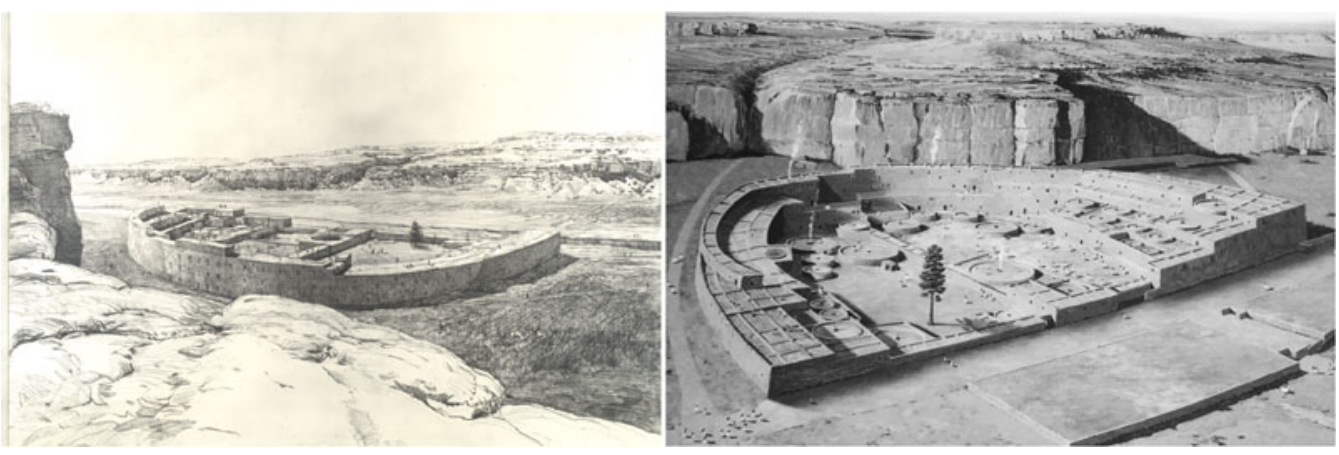

Figure 1. Artist renditions of Pueblo Bonito that include the plaza tree. Left: Drawing by Kenneth Conant, 1926 (from Judd 1964; courtesy of the National Anthropological Archives, Smithsonian Institution, judd_artwork_56). This is possibly the earliest depiction of the tree and is one of two produced by Conant. The tree may have been added to the original drawing with Judd's help after A. E. Douglass cross-dated the tree's rings (see Stein et al. 2003:39-40, 60). Right: A modern, computer-aided depiction from National Park Service signage (courtesy of Dr. Wirt H. Wills).

Wills (2012) countered Judd's interpretation of the Plaza Tree with an examination of the stratigraphy of the west plaza of Pueblo Bonito. He used data from a 1920s test pit located roughly $5 \mathrm{~m}$ from where the tree was uncovered (Roberts 1927). Wills shows that the "last utilized pavement" is $3.3 \mathrm{~m}$ above the Pueblo I (AD 750850 ) surface and, based on ceramic types, the surface postdates $\mathrm{AD} 1100$. Because the tree started growing before AD 732, Wills (2012) reasonably concluded that the tree could not have grown on the post-1100 surface. As an alternative origin, Wills proposed that the tree was likely from Chaco Canyon and that it was brought into
Pueblo Bonito sometime after 1100 by Chacoan people, or possibly much later by American homesteaders (the Wetherill family in particular), or Navajo residents of the canyon during various ranching and building activities that took place in the late nineteenth century.

Reynolds and others (2005) included JPB-99 in their strontium isotope $\left({ }^{87} \mathrm{Sr} /{ }^{86} \mathrm{Sr}\right)$ provenance tests of great-house timbers from Chaco Canyon. Strontium isotopes provide a powerful means to test likely source areas because the ${ }^{87} \mathrm{Sr} /{ }^{86} \mathrm{Sr}$ isotope ratio varies with parent bedrock material and local dust, and it is taken up and preserved in plants. Based on existing literature, Reynolds

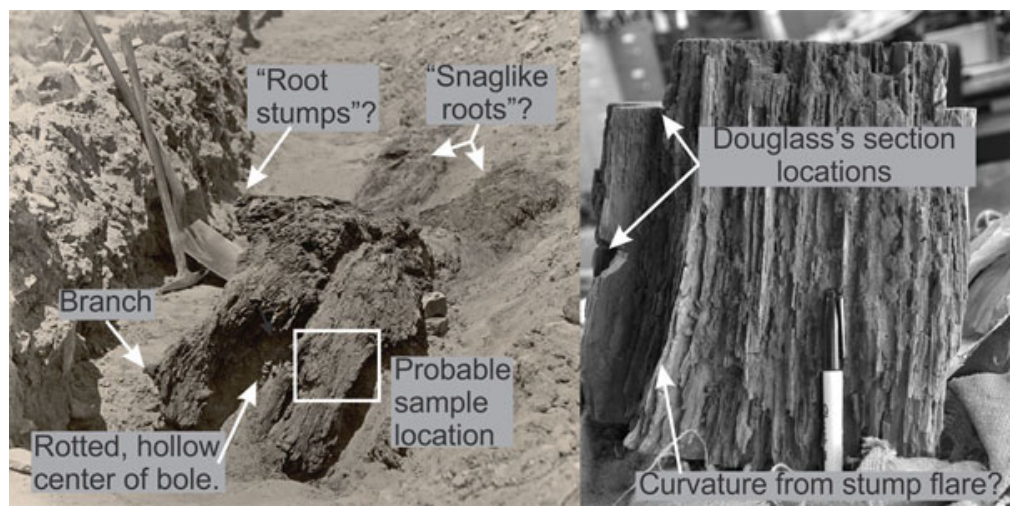

Figure 2. Photos of JPB-99. Left: The excavated log in the west courtyard (photo by O. C. Havens, 1924. \#28416-A, Neil Judd papers, courtesy of the National Anthropological Archives, Smithsonian Institution). Right: The specimen of JPB-99 archived in the Laboratory of Tree-Ring Research (photo by Christopher Guiterman). The specimen is oriented upward in the vertical growth direction. Small samples of JPB-99 were removed in the 1920s by A. E. Douglass to examine its rings. We removed a larger sample to apply modern tree-ring sample processing and dating techniques. 


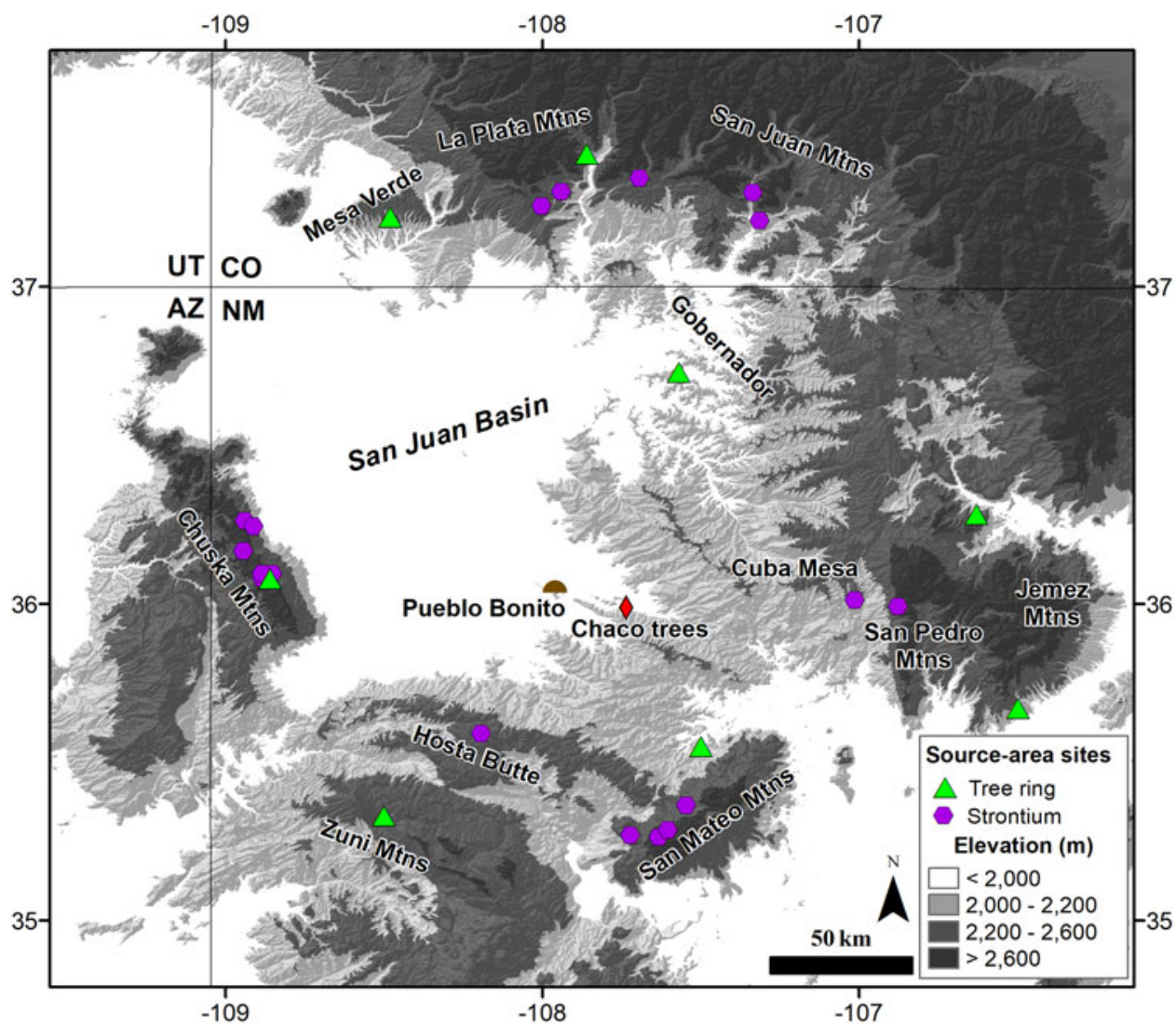

Figure 3. Regional map of the San Juan Basin in northwestern New Mexico showing the site locations for source-area tree-ring chronologies (Guiterman et al. 2016) and strontium isotopes (English et al. 2001; Reynolds et al. 2005). The locations for Pueblo Bonito and the collection of living trees in Chaco Canyon are also shown. (Color online)

and others (2005) assumed that the Plaza Tree had grown in Pueblo Bonito, and they used it to represent an in situ Chaco Canyon tree. Their ${ }^{87} \mathrm{Sr} /{ }^{86} \mathrm{Sr}$ value for JPB-99 is 0.70943 , which falls within the range of ${ }^{87} \mathrm{Sr} /{ }^{86} \mathrm{Sr}$ from modern trees collected in the distant Chuska and La Plata Mountains. It is also comparable to ${ }^{87} \mathrm{Sr} /{ }^{86} \mathrm{Sr}$ of dozens of great-house timbers that were likely brought from distant forested areas (English et al. 2001; Reynolds et al. 2005). There was no attempt in these or other studies to sample living trees from Chaco Canyon in order to evaluate a possible local origin for JPB-99.

Until now, no study has analyzed the tree-ring growth pattern preserved on JPB-99 in comparison with tree-ring chronologies from the region as a means of assessing its provenance. Correlation (and $t$-tests) of tree-ring width chronologies to test for probable growth origins of ancient wood artifacts or timbers (i.e., "dendroprovenance" testing) has been widely used in Europe (Bridge 2012). These methods have also recently been demonstrated in several North American studies (Creasman et al. 2015; Martin-Benito et al. 2014), including our study in Chaco Canyon (Guiterman et al. 2016). Chaco Canyon is located near the center of the $12,000 \mathrm{~km}^{2} \mathrm{San}$ Juan Basin, which is ringed by forested mountain ranges (Figure 3). Guiterman and others (2016) assembled a network of eight tree-ring chronologies (each the average of many standardized ringwidth growth series from a site) surrounding the San Juan Basin to represent potential source areas for archaeological timbers excavated from Chaco Canyon great houses. They assessed the accuracy of dendroprovenance across the network using living trees of known origin to show that ring-width growth patterns of 
individual trees can be used to correctly identify the area from which the trees came. These results support the use of tree-ring width-based sourcing to test the potential for a distant origin of JPB-99.

Here, we closely examine the possible origins of the Plaza Tree using multiple lines of evidence, including (1) documents pertaining to its discovery and analyses, (2) new ${ }^{87} \mathrm{Sr} /{ }^{86} \mathrm{Sr}$ data for the Plaza Tree in comparison with new ${ }^{87} \mathrm{Sr} /{ }^{86} \mathrm{Sr}$ from 12 ponderosa pine trees currently growing in Chaco Canyon, and (3) tree-ring width-based sourcing of the tree and the modern Chaco pines against the network of tree-ring chronologies in the San Juan Basin. We examine three hypotheses:

H1: The Plaza Tree grew where it was found, confirming Judd's origin narrative.

H2: The Plaza Tree did not grow at Pueblo Bonito, but it originated from within or near Chaco Canyon.

H3: The Plaza Tree originated from a distant forested mountain range and was transported to Pueblo Bonito.

\section{Methods and Materials}

\section{Documentary Records}

Much of what we know about the Plaza Tree comes from Judd's (1954) description, published 30 years after the tree was uncovered. In his account (quoted above), there is little detail concerning his initial impressions. For a better sense of what the tree looked like in situ and for Judd's initial interpretations, we searched for photographic and written accounts of the discovery. This search led to three sources of documentary information.

First, we searched through Judd's papers in the online database of the Chaco Research Archive (www.chacoarchive.org) for scanned copies of his 1924 field notes and specimen cards, as well as any other materials that might relate to the Plaza Tree (including photographs). This online archive includes the sum of Judd's papers from the National Anthropological Archives, which totals 14 linear feet (Glenn 1982). Second, we searched through correspondence between Judd and A. E. Douglass at the University of Arizona from 1921 to 1963 , which might hold pertinent information because Judd had sent Douglass a sample from the tree. This document record is not included in the online archives from the Smithsonian Institution because shortly after Douglass's death in 1963, Judd sent his copies of their correspondence to the Laboratory of Tree-Ring Research (LTRR) at the University of Arizona in Tucson as a record of the development of dendrochronology and the archaeology of Chaco Canyon. Finally, we searched Douglass's files pertaining to archaeological specimens that are housed at the LTRR. These files mainly consist of specimen notes, data notecards, and skeleton plots (a graphing paper-based tool for dendrochronological cross-dating; Stokes and Smiley 1968). Douglass was a prolific notetaker, and these historical records open a window into his observations and thoughts contemporaneous with his laboratory work. In addition to unpublished sources of information, we searched the literature regarding Pueblo Bonito, Chaco Canyon, and early tree-ring dating to find any available references to or descriptions of JPB-99.

\section{Strontium Isotopes}

To ensure a well-replicated representation of the ${ }^{87} \mathrm{Sr} /{ }^{86} \mathrm{Sr}$ composition of JPB-99, we obtained three new samples from the tree. We examined these along with the sample obtained by Reynolds and others (2005) from the innermost rings of JPB-99, dating to the AD 730s. Our samples came from wood formed later in the tree's life but still within the heartwood, specifically at $\mathrm{AD} 813$, the 850s, and 916-918.

We also obtained ${ }^{87} \mathrm{Sr} /{ }^{86} \mathrm{Sr}$ values from 12 living Chaco Canyon ponderosa pines included in the Chaco East tree-ring collection made by R. Gwinn Vivian and Thomas Windes (Windes 2018; Figure 3). The Chaco East site consists of 27 trees with ring series spanning from AD 1372 to 1994 . The trees grow in three clusters located in small north-facing canyon alcoves 22 $\mathrm{km}$ east of Pueblo Bonito. These clusters of trees constitute the nearest stands of ponderosa pine to the Chaco Core area that include tree-ring dating, collection notes, photographs, and 
locations within Chaco Canyon itself. They are, therefore, the best available collection of living ponderosa pines from Chaco Canyon. Several individual trees and $\operatorname{logs}$ have been found closer to Pueblo Bonito (Douglass 1935; Judd 1954). In 2011, we searched Chaco Canyon to find the locations of the $\operatorname{logs}$ that Judd described and photographed, but the wood was gone, so we could not obtain our own samples or confidently tie specimens archived at the LTRR to Judd's publications. $^{1}$

Our new ${ }^{87} \mathrm{Sr} /{ }^{86} \mathrm{Sr}$ data were obtained and processed following standard procedures (English et al. 2001). The samples consisted of approximately $70 \mathrm{mg}$ of wood that we preprocessed and carbonized at the University of Arizona. The ash was dissolved in triple distilled acids and analyzed on a Neptune Multicollector Inductively Coupled Plasma Mass Spectrometer (MC-ICP-MS) at the James Cook University Advanced Analytical Center in Townsville, Australia. The ${ }^{87} \mathrm{Sr} /{ }^{86} \mathrm{Sr}$ ratios were measured on Faraday collectors in static mode, with a total runtime of approximately 16 minutes. All isotopic ratios were normalized to an ${ }^{86} \mathrm{Sr} /{ }^{88} \mathrm{Sr}$ ratio of 0.1194. Negligible corrections for krypton $(\mathrm{Kr})$ and rubidium $(\mathrm{Rb})$ interferences are observed for samples with ${ }^{88} \mathrm{Sr}>1.5 \mathrm{~V}$, but these corrections are included in our data reduction. For samples with ${ }^{88} \mathrm{Sr}<1.5 \mathrm{~V}$, interference on ${ }^{87} \mathrm{Sr}$ by ${ }^{87} \mathrm{Rb}$ occurs. This interference is not negligible, and verification of accurate correction for $\mathrm{Rb}$ interference was accomplished by repeat measurements of the $\mathrm{Sr}$ standard NBS-987 at variable concentrations. Analyses of the NBS-987 standard that were run in conjunction with the samples yielded a mean ratio of 0.71026 .

Analyses of the strontium data followed established methods (English et al. 2001). We included previously published data with our new samples, but we only included ${ }^{87} \mathrm{Sr} /{ }^{86} \mathrm{Sr}$ obtained from trees to limit potential variability in ${ }^{87} \mathrm{Sr} /{ }^{86} \mathrm{Sr}$ ratios when mixing sources. We used Wilcoxon-Mann-Whitney tests of medians to evaluate differences among our new Chaco data, JPB-99, and other ${ }^{87} \mathrm{Sr} /{ }^{86} \mathrm{Sr}$ data.

\section{Tree-Ring Sourcing}

As an independent test of origin for the Plaza Tree, we compared the single tree-ring width series of JPB-99 to each tree-ring site chronology across the network of eight sites surrounding the San Juan Basin (Guiterman et al. 2016). Ideally, we would also compare JPB-99 to a control site in Chaco Canyon, but there is no local tree-ring master chronology that extends back in time early enough (i.e., AD 700s-900s) to directly compare with the JPB-99. A chronology built from Chaco great-house timbers also cannot be used because it would contain a majority of nonlocal trees (Guiterman et al. 2016). The oldest known local tree from Chaco Canyon is a remnant Douglas fir (Pseudotsuga menziesii; LTRR specimen CHM-190) that was found on the ground near the East Community great house (29Mc 560), dating to AD 917-1574 (Windes 2018). Dendroprovenance testing requires contemporaneous tree-ring sequences, and it is most effective when the source-area chronology is built from many trees in order to amplify the regional dendroclimatic signature of the site. Because there is only a single tree in Chaco Canyon that grew contemporaneously with JPB-99, we designed a partial-analog test that assesses similarity/dissimilarity of spatial patterns during noncontemporary time periods. The test follows Guiterman and others (2016) and consists of using the 12 living Chaco Canyon ponderosa pines sampled for strontium isotope analysis as if they were of unknown origin and correlating their growth series to the network of source-area sites surrounding the San Juan Basin. We expect that the living Chaco Canyon pines would have some unique local ring-width patterns, but that they would still show a consistent "souring" pattern with one or more source-area chronologies. The spatial pattern would originate from similar regional climatic influences on tree growth between the canyon and a subset of the source-area site locations. The pattern across the 12 living pines would therefore reflect the sourcing results for trees of local, Chaco Canyon origin, regardless of the time period, assuming relatively stable dendroclimatic patterns over the last millennium or longer. Consequently, should the sourcing results for JPB-99 reflect the overall pattern for the Chaco Canyon pines, we would interpret that to mean that JPB-99 originated from Chaco Canyon, and possibly from Pueblo Bonito. 
Sourcing tests followed previous methods (Guiterman et al. 2016), including standardization of measured tree-ring widths to remove the biological growth trend, and then removal of withinseries autocorrelation by autoregressive modeling. Each tree-ring series was correlated against the regional network of source-area chronologies. We had 13 trees (JPB-99 plus 12 living Chaco pines) and eight source-area chronologies, totaling 104 individual correlations. We assessed the strength of these correlations after conversion to $t$-values in order to scale the values by their length of overlap. Significance of the correlations was assessed with one-tailed $t$ tests $(\alpha=0.01)$.

\section{Results}

\section{Documentary Evidence}

The papers of Neil Judd available online at the Chaco Research Archive include a single brief note regarding the Plaza Tree. It provides the same information as Judd's (1954:3) description quoted above. As cited in Stein and colleagues (1997:145), Judd's notes for the West Court, Card 3 (page 233 of scanned CDI accession number 000174), explains, "In 1924 on the last occupied surface @ S. end of W. Ct. we came upon the decayed remains of a large pine that obviously had grown here (tree-ring sample JPB\#99)." A handwritten declaration on the top of Judd's notecards for the section on Pueblo Bonito's west courtyard states that these notes are "condensed and clarified," possibly indicating that more detailed field notes exist elsewhere. We were unable to obtain any more detailed notecards because original field notes were not found with Judd's papers at the National Anthropological Archives when these materials were examined and scanned for the Chaco Research Archive (Stephen Plog, personal communication 2019).

We found several mentions of the Plaza Tree in the correspondence between Judd and Douglass on file at the LTRR. Beginning with a letter dated June 11, 1924, Judd describes wood specimens excavated from Pueblo Bonito that were delivered to Douglass shortly thereafter. The following excerpt from Judd's letter to Douglass is the earliest mention of JPB-99 that we have found:
You will be especially interested in section 99 , cut from near the roots of a large and partially decayed log found in the west court of Bonito. It lay very close to the surface and from the root stumps led me, at first, to believe the tree had grown where it fell. But failure to find any trace of decayed roots forced me to abandon this possibility. The unwieldly butt would have made it impossible to carry the 20 foot log any great distance, at any rate. I shall be much interested to learn from your examination whether its rings add anything to what we have heretofore obtained from Chaco Canyon [personal correspondence from N. Judd to A. E. Douglass, June 11, 1924, LTRR Files; emphasis added].

The next mention of the tree comes three years later, in 1927, when Judd appears to grow impatient for information pertaining to "section 99":

Our \#99 was taken from a much decayed, 20 foot $\log$ found much (just) below the surface during excavation of the southwestern quarter of the West Court of Bonito. Since portions of the roots were still attached to the trunk, it seemed unlikely to me that this log could have been carried any great distance; however, I saw no evidence that the pine had grown where we found it. Its rings, if readable, should be among the latest record from Bonito [personal correspondence from N. Judd to A. E. Douglass, May 6, 1927, LTRR Files; strikeout and word "just" added to original (in pencil, presumably by Judd); emphasis added].

These letters contradict Judd's published account of the tree. Since we cannot locate field notes, they are the closest we can get to contemporaneous observations of his discovery. It appears that Judd initially thought the tree grew in the west courtyard--"from the root stumps led me, at first, to believe the tree had grown where it fell"- - but after looking for and not finding any trace of decayed roots, he "abandon[ed]" that interpretation. Three years later, in May 1927, returning to the subject, he wrote, "I saw no evidence that the pine had grown where we found it." Nevertheless, in his 1954 published 
description, he reasserted the interpretation that a living JPB-99 had grown in the west courtyard of Pueblo Bonito.

It was after the second letter that Douglass first examined JPB-99. The earliest dated skeleton plot of the tree that we found is from June 24, 1927-nearly two months after Judd wrote his letter. Douglass ended his work with the written word "Dated," which he later crossed out. It would take Douglass at least two more attempts to cross-date the tree's rings. We found skeleton plots from April 29, 1928 and August 29, 1928. On the back of this final skeleton plot, Douglass writes, "The log must have been 24 [inches] in diameter and probably too big to use after bringing in. The color is very dark mahogany and I ought to have recognized its age" (A. E. Douglass, notes, LTRR Files, August 28, 1928). Douglass reported his findings to Judd in the last sentence of a six page letter: "I also send a few recent datings [sic] including JPB99 which we thought was gap material but proves to be early PB" (personal correspondence from A. E. Douglass to N. Judd, LTRR Files, August 21, 1928). This brief statement that the plaza tree dates to the early period of the Pueblo Bonito chronology is the last mention of the tree we found in the correspondence between Judd and Douglass.

The reference Douglass makes to the wood color on JPB-99 suggests that he was surprised by his discovery. As remnant logs and some architectural wood age, they tend to darken. Following Judd's description in his May 1927 letter that the tree "should be among the latest record from Bonito," Douglass thought the tree would be younger, possibly from a post-Chacoan period. It is indeed a rare discovery that a tree, with roots attached, was lying buried in a courtyard for over roughly 1,000 years and that it had withstood not only the elements but also the construction and occupation of a major village structure. Douglass also felt that the large log was too big for use, which might have explained to him why it was found in the plaza instead of in the structure. We know now that many $\operatorname{logs}$ as big or bigger than JPB-99 were indeed brought to and used in Pueblo Bonito and other structures (Betancourt et al. 1986; Snygg and Windes 1998).
Table 1. Values of ${ }^{87} \mathrm{Sr} /{ }^{86} \mathrm{Sr}$ for the Plaza Tree (JPB-99) and Modern Chaco Canyon Ponderosa Pines.

\begin{tabular}{lcc}
\hline Specimen ID & ${ }^{87} \mathrm{Sr} /{ }^{86} \mathrm{Sr}$ & Standard Error \\
\hline JPB-99Aa-1 & 0.70931 & 0.000007 \\
JPB-99Aa-2 & 0.70934 & 0.000009 \\
JPB-99Aa-3 & 0.70929 & 0.000006 \\
CHA-31 & 0.71016 & 0.000037 \\
CHA-28a & 0.71023 & 0.000048 \\
CHA-30 & 0.71046 & 0.000029 \\
CHA-39e & 0.71002 & 0.000074 \\
CHA-38a & 0.71006 & 0.000030 \\
CHA-54 & 0.71017 & 0.000013 \\
CHA-35 & 0.70958 & 0.000014 \\
CHA-56 & 0.71031 & 0.000037 \\
CHA-27b & 0.71112 & 0.000042 \\
CHA-46 & 0.70987 & 0.000019 \\
CHA-22b & 0.71005 & 0.000020 \\
CHA-49b & 0.70966 & 0.000023 \\
\hline
\end{tabular}

\section{Strontium Isotopic Evidence}

The ${ }^{87} \mathrm{Sr} /{ }^{86} \mathrm{Sr}$ ratios that we obtained for living Chaco Canyon ponderosa pine trees $(n=12)$ range from 0.70958 to 0.71112 (Table 1). This

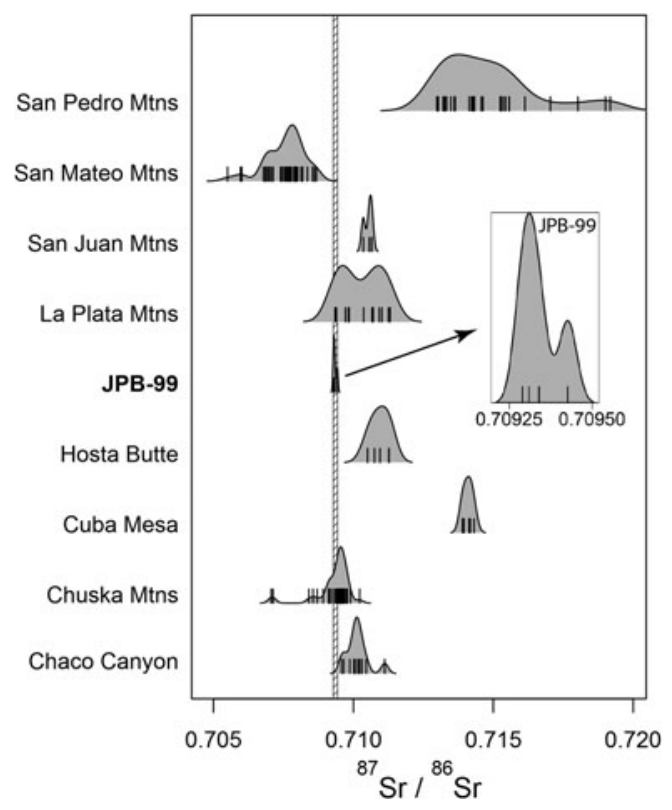

Figure 4. Values of ${ }^{87} \mathrm{Sr} /{ }^{86} \mathrm{Sr}$ for the Plaza Tree (JPB-99, inset) and modern trees from locations surrounding the San Juan Basin. The hashed bar denotes the range of the four values for JPB-99, with detail provided in the inset. All values are shown by the vertical marks with kernel density plots for each location. 
Table 2. Differences of Medians for ${ }^{87} \mathrm{Sr} /{ }^{86} \mathrm{Sr}$ values between Potential Growth Locations of the Plaza Tree.

\begin{tabular}{|c|c|c|c|c|c|c|c|}
\hline & $\begin{array}{c}\text { Chuska } \\
\text { Mtns }\end{array}$ & Cuba Mesa & Hosta Butte & $\begin{array}{c}\text { La Plata } \\
\text { Mtns }\end{array}$ & $\begin{array}{c}\text { San Juan } \\
\text { Mtns }\end{array}$ & $\begin{array}{c}\text { San Mateo } \\
\text { Mtns }\end{array}$ & $\begin{array}{c}\text { San Pedro } \\
\text { Mtns }\end{array}$ \\
\hline Chaco Canyon & $0.0006^{* * *}$ & $-0.0040 * * *$ & $-0.0008 * *$ & -0.0003 & $-0.0005^{*}$ & $0.0024 * * *$ & $-0.0042^{* * *}$ \\
\hline Chuska Mtns & & $-0.0046^{* * *}$ & $-0.0014 * * *$ & $-0.0009 * * *$ & $-0.0011 * * *$ & $0.0018^{* * *}$ & $-0.0048^{* * *}$ \\
\hline Cuba Mesa & & & $0.0032 * *$ & $0.0038 * * *$ & $0.0036^{*}$ & $0.0065^{* * *}$ & -0.0002 \\
\hline Hosta Butte & & & & $0.0006^{*}$ & 0.0004 & $0.0033^{* * *}$ & $-0.0034^{* * * *}$ \\
\hline La Plata Mtns & & & & & -0.0002 & $0.0027 * * *$ & $-0.0040^{* * *}$ \\
\hline San Juan Mtns & & & & & & $0.0029 * * *$ & $-0.0038^{* * *}$ \\
\hline San Mateo Mtns & & & & & & & $-0.0066^{* * *}$ \\
\hline
\end{tabular}

Notes: All strontium samples were obtained from trees. Asterisks indicate significance levels. Highly significant test results indicate that the two source areas can be distinguished via ${ }^{87} \mathrm{Sr} /{ }^{86} \mathrm{Sr}$ of trees. For example, the Chuska Mountains and Chaco Canyon have distinctly different strontium signatures.

Significance of two-sample Mann-Whitney tests:

$* * * p<0.001$

$* * p<0.01$

$* p<0.1$

distribution of ${ }^{87} \mathrm{Sr} /{ }^{86} \mathrm{Sr}$ ratios for Chaco Canyon pines is relatively low, and it overlaps to some degree with other potential source locations around the San Juan Basin (Figure 4). Tests of medians among the source locations, however, show that Chaco Canyon has a distinct ${ }^{87} \mathrm{Sr} /{ }^{86} \mathrm{Sr}$ composition, distinguishable from all source areas but the La Plata Mountains in southern Colorado (Table 2). Most other source areas are also independently distinguishable based on ${ }^{87} \mathrm{Sr} /{ }^{86} \mathrm{Sr}$ ratios obtained from trees.

The ${ }^{87} \mathrm{Sr} /{ }^{86} \mathrm{Sr}$ values we obtained from JPB-99 range from 0.70929 to 0.70934 (Table 1). Because these values are close to the previously published value $(0.70943$; Reynolds et al. 2005), we include the Reynolds and others data in our analyses. The narrow distribution of the four ${ }^{87} \mathrm{Sr} /{ }^{86} \mathrm{Sr}$ ratios for JPB-99 overlap with three potential source areas (Figure 4): the La Plata Mountains in Colorado, the Chuska Mountains $50 \mathrm{~km}$ west on the Arizona border, and Chaco Canyon, where the tree was discovered. Visually, JPB- $99{ }^{87} \mathrm{Sr} /{ }^{86} \mathrm{Sr}$ ratios align best with the Chuska Mountains. The ${ }^{87} \mathrm{Sr} /{ }^{86} \mathrm{Sr}$ for JPB-99 falls on the tails of the distributions for the La Plata and Chaco Canyon trees, lowering our confidence that these are good matches. Statistical testing supports the visual comparison and suggests that, based on ${ }^{87} \mathrm{Sr} /{ }^{86} \mathrm{Sr}$ ratios, the most probable source area for JPB-99 is the Chuska Mountains (Table 3).
Table 3. Differences of Medians for ${ }^{87} \mathrm{Sr} /{ }^{86} \mathrm{Sr}$ values between the Plaza Tree (JPB-99) and Its Most Probable Source Locations.

\begin{tabular}{lc}
\hline & JPB-99 \\
\hline Chaco Canyon & $0.0008^{* *}$ \\
Chuska Mtns & -0.0002 \\
La Plata Mtns & $-0.0010^{* *}$ \\
\hline
\end{tabular}

Note: Italicized text indicates no detectable difference. $* * * p<0.001$

$* * p<0.01$

$* p<0.1$

\section{Tree-Ring Evidence}

Tree-ring width-based sourcing for JPB-99 revealed a strong and significant correlation to the Chuska Mountains chronology ( $t=$ 11.0; Figure 5a). Although the Plaza Tree also had significant correlations with each of the other source areas, earlier evaluation of this method confirmed that the highest correlation is more than $90 \%$ accurate in determining the true growth location for a tree (Guiterman et al. 2016). In the case of JPB-99, the second highest correlation is with the Gobernador area northeast of Chaco Canyon, with a substantially lower correlation $(t=9.7)$ than with the Chuska Mountains.

Had JPB-99 grown in Chaco Canyon, we would expect to find that its correlations to distant source-area chronologies would match the pattern of the living trees from Chaco Canyon, reflecting regional climate influences on tree 

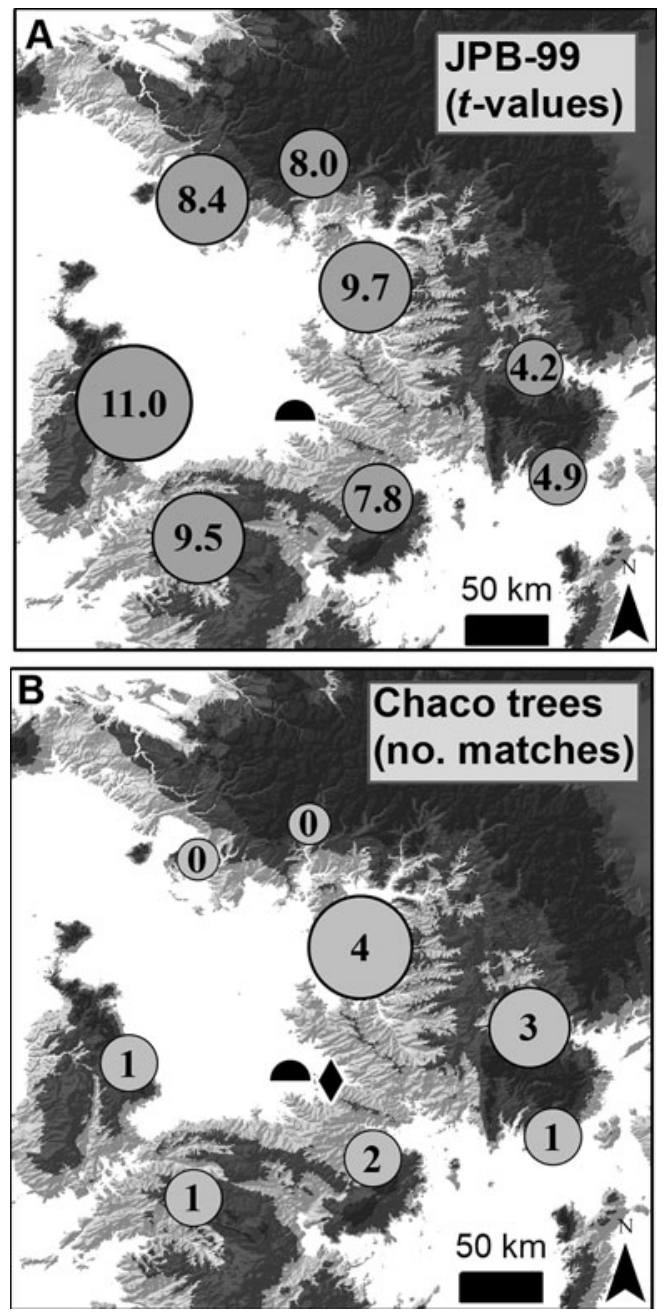

Figure 5. Tree-ring provenance testing of the Plaza Tree (A) and 12 living Chaco Canyon ponderosa pines (B). The living trees provide a partial analog test for a local canyon origin of JPB-99. In (A), numbers at each source-area location show $t$-values for the correlations of JPB-99 with each source-area chronology. In (B), numbers show how many live Chaco trees (out of 12) have their best match to each source-area chronology.

growth. The 12 living Chaco Canyon pines, however, had the most numerous and the strongest correlations with mountain ranges to the east of Chaco Canyon (Figure 5b). This pattern directly contrasts the sourcing results for JPB-99, lending support for a growth origin outside of Chaco Canyon. Overall, the tree-ring width-based sourcing method strongly indicates a Chuska Mountains origin for JPB-99 (Figure 6).

\section{Discussion}

The Plaza Tree of Pueblo Bonito has stimulated the imaginations of archaeologists and visitors to Chaco Canyon since 1924 when it was first excavated. The legend of the tree has grown since then. The iconic tree is depicted on the Chaco Culture National Historical Park brochure as a large, living ponderosa pine growing in the west courtyard of Pueblo Bonito at the peak of Chacoan florescence. But is this true? Was it, as Neil Judd and A. E. Douglass surmised (Douglass 1935; Judd 1954), a remnant of a once-expansive pine forest in Chaco Canyon, felled to build the great houses? Was it, as some have suggested (Ashmore 2007; Stein et al. 1997), important in the constructed location and directionality of Pueblo Bonito so that it could be used like the gnomon on a sundial to cast shadows across important kivas during seasonal solar events? If it was an emplaced dead tree (pole) rather than an in situ living tree (Wills 2012), did it still serve these purposes? Finally, the most basic question of all: Where did it grow? Here, we tested the various origin speculations about the Plaza Tree by examining multiple lines of evidence pertaining to its discovery, geochemical signature, and tree-ring growth patterns.

Few documents pertaining to the Plaza Tree remain from Judd's 1924 expedition, which discovered the tree in a trench through the west courtyard of Pueblo Bonito. We found the best available perspectives of the tree located in situ from a series of letters between Judd and Douglass, who collaborated to produce the first tree-ring dates for Chaco Canyon great houses. These letters make it clear that Judd remained interested in the tree's origin from the day he found it until the end of his career. He urged Douglass for three years to examine the specimen, and then almost 30 years later published his version of its origin story (Judd 1954). Through this period, however, his interpretations shifted dramatically. In a letter to Douglass dated June 11, 1924, in which Judd described the contents of a box of samples being shipped to Douglass, he provided his initial perspective. He was clearly curious about whether it grew in the courtyard, although his own investigation 
A

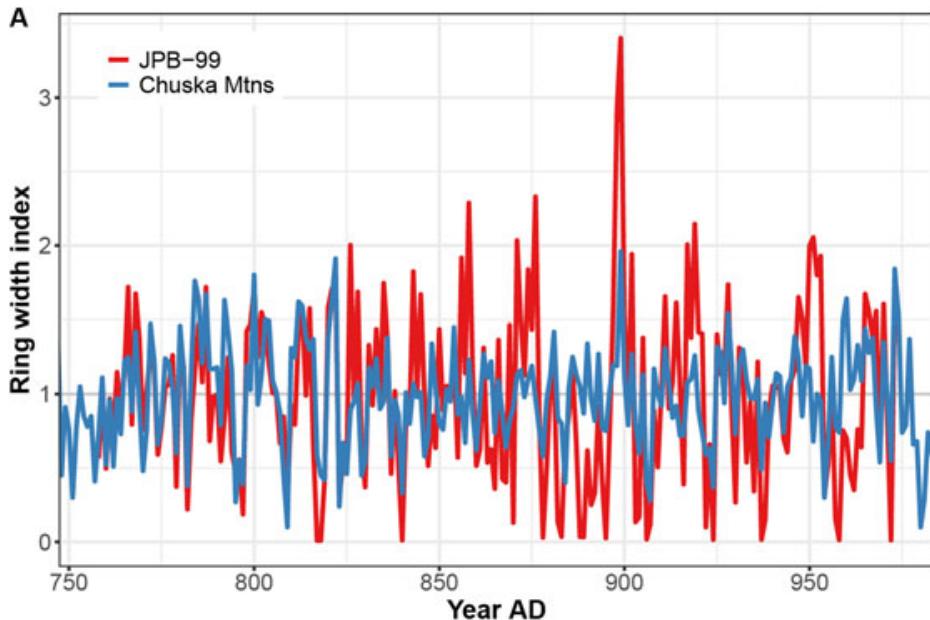

B

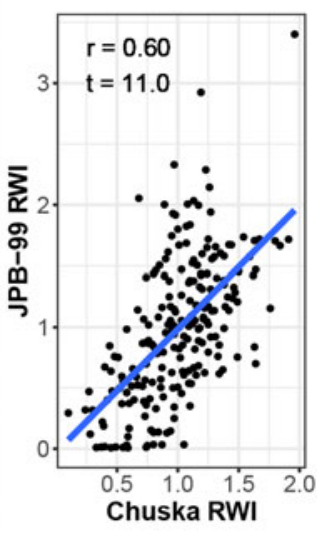

Figure 6. Time series (A) and scatter plot (B) comparisons of tree growth patterns between JPB-99 and the Chuska Mountains tree-ring chronology. (Color online)

suggested that it did not. According to Judd, there was no trace of decayed roots in the soil surrounding the tree. In 1924, he notes the presence of "root stumps" at the base of the log, which contrasts with his description of "great, snaglike roots" in 1954. We speculate that the "root stumps" Judd refers to are the stub ends of primary roots that can be seen in the photograph by O. C. Havens (Figure 2). We wonder if these root ends looked to Judd as if they had been cut off, hence the use of the words "root stumps" in the 1924 letter.

Written correspondence between Judd and Douglass in the available record regarding JPB-99 ceases after 1928. We think this might relate to a particular sequence of events over the next year or so. In his urging Douglass to examine JPB-99, Judd indicated that he thought the tree should help in their overall efforts to obtain calendar dating for Pueblo Bonito. $\mathrm{He}$ wrote that the tree "should be among the latest record from Bonito" because he believed it could not have been carried far, and it was found "just below" the modern ground surface (personal correspondence, 677 N. Judd to A. E. Douglass, 1927). Douglass confirmed that although he and Judd had originally suspected JPB-99 to be "gap material," it actually dates to the period of Pueblo Bonito construction and occupation, preceding the "gap." The "gap" refers to the period between the beginning of
Douglass's living tree-ring chronology of absolute calendar-based dates and the end of a "floating chronology" he created to aid in assigning relative tree-ring dates to archaeological timbers from Pueblo Bonito and other sites. Douglass, Judd, and others spent much of the late 1920s in search of archaeological sites and timbers that would connect (or bridge) the living trees to the set of relatively dated beams.

In 1929, Douglass "bridged the gap" between modern trees and the floating archaeological tree-ring record, thereby revealing exact construction dates for dozens of ruins in Chaco Canyon and across the Southwest (Douglass 1929; Haury 1962; Nash 1999). Judd was part of the Third Beam Expedition in 1929 with Douglass, making it plausible that the two discussed JPB-99 and its possible significance. Perhaps these discussions stimulated Judd's evolving interpretation for the Plaza Tree. Prior to knowing the tree-ring dates, Judd thought it was simply a decayed $\log$ that might prove useful in building the Pueblo chronology. It is doubtful he thought that it would shape his vision of the prehistoric site. Presented with the tree's actual chronology, and after several decades, Judd's interpretation shifted quite dramatically. $\mathrm{He}$ now envisioned a large, living Plaza Tree in the west courtyard, preserved as a grand and significant relic of a felled forest in Chaco Canyon. The ponderosa pine logs along the rim of Chaco 
Canyon that Judd visited with his Navajo guides suggested that the canyon could have once sustained a ponderosa pine forest. The revelation paved the way for Judd to interpret a local origin for hundreds of thousands of pine beams used to construct the great houses (Judd 1954). Modern paleoecological and provenance methods have since revealed that construction timbers were brought great distances into Chaco Canyon because local wood sources were virtually nonexistent at the time (Betancourt and Van Devender 1981; Betancourt et al. 1986; English et al. 2001; Guiterman et al. 2016; Reynolds et al. 2005). Could the Plaza Tree also have been brought from a distant mountain range?

Previous studies of construction timbers from Chaco Canyon point to distant mountain ranges to the south and west as probable timber procurement areas (English et al. 2001; Reynolds et al. 2005). These studies, however, were somewhat limited by a lack of samples from living Chaco Canyon trees that could have provided a local control for comparison. This knowledge gap led some researchers (Drake et al. 2014) to argue that potential source areas cannot be distinguished from Chaco Canyon, and to conclude that most great-house timbers (especially ponderosa pines), including JPB-99, are likely to have originated locally in Chaco Canyon or from small sites east and south of the canyon. By obtaining 12 new ${ }^{87} \mathrm{Sr} /{ }^{86} \mathrm{Sr}$ values from trees that grow in Chaco Canyon, we show that this is not the case: Chaco Canyon, the Chuska Mountains, and all other nearby forested mesas and mountain ranges, except the La Plata Mountains in Colorado, are statistically distinguishable (Table 2). These findings help to confirm the conclusions of strontium-based sourcing of great-house timbers (English et al. 2001; Reynolds et al. 2005). Now with three new ${ }^{87} \mathrm{Sr} /{ }^{86} \mathrm{Sr}$ values for JPB-99, we find that its overall ${ }^{87} \mathrm{Sr} /{ }^{86} \mathrm{Sr}$ signature is different from trees in Chaco Canyon, the La Plata Mountains, and other potential source areas. The Plaza Tree of Pueblo Bonito has a ${ }^{87} \mathrm{Sr} /{ }^{86} \mathrm{Sr}$ signature that is consistent with having been sourced from the Chuska Mountains (Table 3; Figure 4).

The tree-ring growth pattern of JPB-99 presents another independent means of assessing the tree's probable origins and corroborating the strontium-sourcing results. The JPB-99 growth pattern matches regional signatures of tree growth in northern Arizona and New Mexico-that is, in dendrochronological terms, it "cross-dates." This is only possible for trees that are sensitive to the interannual variability of precipitation in the region and that maintain growth rates high enough to form a dependable tree-ring growth series for dating. In general, trees from too wet an area can lack interannual variability in their growth patterns, and they are difficult to cross-date. In low-elevation and dry areas, trees can be so suppressed by drought that they cannot be cross-dated because of too many missing rings during long dry periods with very little growth (Fritts et al. 1965). We found that the ring pattern of JPB-99 is not overly suppressed by drought. The living trees we assessed from Chaco Canyon have similar growth and cross-dating characteristics, probably because of unique microsite conditions in a set of north-facing alcoves with adequate soil moisture (possibly from seeps or springs) despite the low elevation. Tree groups such as this are rare in Chaco and other nearby canyons because of the dry conditions. The several pine trees found closer to Pueblo Bonito by Judd and his guides might have been sampled and could not be cross-dated because their ring growth was overly suppressed by drought. ${ }^{2}$ If JPB-99 had been growing in Pueblo Bonito, the harsh, dry conditions would likely have suppressed its growth beyond what could be crossdated. Without knowing its ancient dates, Judd might not have reported the discovery so many years later. Soil compaction in the west plaza by centuries of foot traffic would have also likely added further growth suppression (Kozlowski 1999), but we do not see anomalous growth or long-term decline. ${ }^{3}$ In short, the tree-ring growth preserved on JPB-99 is more consistent with trees growing in the mid-elevation forests and woodlands of northern New Mexico than trees growing in low-elevation canyons like Chaco Canyon.

To test for a probable origin of JPB-99 in or outside of Chaco Canyon, we employed tree-ring sourcing methods (Guiterman et al. 2016). We could not compare JPB-99 to contemporaneously growing trees from Chaco Canyon, so 
we created a partial analog test using living Chaco Canyon trees. The test assumes that the relative spatial patterns of local trees and regional mountain-range chronologies have been relatively stable over the past millennium. It is less powerful or potentially conclusive than standard dendroprovenance tests of contemporaneous trees, but we consider it an additional, even if limited, line of evidence. The test shows that most Chaco Canyon pines correlate the strongest with source-area chronology sites to the east or south of Chaco Canyon. The Plaza Tree, by contrast, has a maximum correlation to the Chuska Mountains chronology, west of Chaco Canyon. The correlation of JPB-99 to the Chuska Mountains is $t=11.0$, a highly significant and notably strong match to a distant source-area chronology. For perspective, this $t$-value would rank above the ninetieth percentile of $t$-values from all 170 great-house timbers sourced by Guiterman and others (2016). Compared to just the Chuskaorigin timbers, the $t$-value of JPB-99 ranks even higher, above the ninety-third percentile. By opposing the directionality of local trees and strongly matching to a single distant source-area chronology, the growth pattern of JPB-99 underscores that it grew in the Chuska Mountains (Figure 5).

In summary, we posed three hypotheses regarding the probable origins of the Plaza Tree of Pueblo Bonito: (H1) that it grew where it was found, (H2) that it came locally from Chaco Canyon, or (H3) that it was brought in from a distant forested area. The documentary record we obtained regarding the tree in situ, along with recent stratigraphic interpretations of the courtyard (Wills 2012), lead us to reject H1: the Plaza Tree could not have grown in Pueblo Bonito. The ${ }^{87} \mathrm{Sr} /{ }^{86} \mathrm{Sr}$ values of JPB-99 do not match living trees obtained from Chaco Canyon, and our tree-ring test also suggested a nonlocal origin. We therefore reject $\mathrm{H} 2$ : the Plaza Tree is not likely to have grown in Chaco Canyon. Finally, corroborating evidences of ${ }^{87} \mathrm{Sr} /{ }^{86} \mathrm{Sr}$-based and tree-ring-based sourcing point to the Chuska Mountains as the most probable origin for JPB-99, leading us to accept H3: the Plaza Tree was likely brought to Pueblo Bonito from the Chuska Mountains, more than $50 \mathrm{~km}$ away.
Why Was There a Log in the West Courtyard of Pueblo Bonito?

Given over a century of excavations and surveys in the region, JPB-99 is a curious find, indeed. It is one of only two large, nonarchitectural logs that we know of from a major Ancestral Puebloan structure. The other, a $10 \mathrm{~m}$ long white fir (Abies concolor), was apparently placed across the entryway to Kiet Siel in Arizona. That JPB-99 was carried more than $50 \mathrm{~km}$ to Pueblo Bonito is a major feat of human strength and organization, but one that was accomplished for hundreds of thousands of construction timbers, including some timbers of even greater size than JPB-99 (Snygg and Windes 1998). To better understand why the tree was located where it was found, we examine the probable timing of its arrival and how its anatomical features might elucidate its purpose.

A congruence of evidence suggests that the Plaza Tree arrived in Pueblo Bonito sometime after AD 1100 , possibly in the 1120 s or later. First, Wills (2012) pointed out that the surface on which JPB-99 lay-roots and all-dates via ceramics to the post-1100 period. Second, we estimated the tree's death date by applying Nash's (1997) sapwood/heartwood equation for ponderosa pine, assuming that the last ring on JPB-99 dating to AD 981 is the outside of the heartwood. The equation generates an estimate of 148 sapwood (outer) rings that were lost to erosion as the tree's sapwood rotted away underground, yielding a potential death date for JPB-99 of AD $1129 \pm 24$. Finally, excavation of a $2.5 \mathrm{~m}$ wide firebox sunk into the plaza surface near JPB-99 yielded a last-use date of AD 1127. The firebox was excavated in 1952 by R. Gordon Vivian, and the date is based on 29 noncutting tree-ring dates and one cutting date (Robinson et al. 1974:34). We assume that this last-use date is a good estimate for the last use of the plaza surface as well. The confluence of these separate dates suggests that the Plaza Tree arrived sometime between the apex (late 1000s) and decline (mid-1100s) of the Chacoan Phenomenon at Pueblo Bonito.

The location of the tree is a place from which a tall pole could act like the gnomon on a sundial and cast a shadow over several important kivas 
during certain solar events (Ashmore 2007; Stein et al. 1997). Was the tree tall enough to be a gnomon? Judd stated in his letter to Douglass and in later publications that the tree trunk was more than $6 \mathrm{~m}$ (20 ft.) long. What we can see of the tree in its only known photograph (Figure 2, left) looks to be roughly $1 \mathrm{~m}$ (3 ft.) in length, as compared to the shovel in the background of the photo. We have confidence that the specimen sent to Douglass (which we examined in this study) comes from this lower portion of the bole (see Figure 2). The upper portion of the tree that Judd must have included in the overall length estimate must be outside of the photo frame; we lack any material evidence or secondary observation to confirm Judd's assertion regarding the length of the tree. Therefore, a 6 $\mathrm{m}$ long Plaza Tree cannot be verified, although it is not unfounded. A 250-year-old ponderosa pine from the Chuska Mountains will often top $20 \mathrm{~m}$ in total height and yield a log at least $6 \mathrm{~m}$ in length. Although we cannot confirm that JPB-99 was actually long enough to be a gnomon, it is certainly possible.

A tall pole could serve many uses in ceremonies or festivals. We speculate that if JPB-99 had some "root stumps" flaring out at its base, the tree probably would have had greater stability than a straight tree trunk emplaced in the ground. In his letters to Douglass, Judd provides reason to doubt that the tree had roots attached, but the O. C. Havens photo gives the sense that there was some form of roots attached. A tall, emplaced tree trunk in a Puebloan plaza reminds us of the tradition of pole climbing during certain Native American festivals (Leroy 1903; Malotki et al. 2002; Parsons 1933; Parsons and Beals 1934). Pole-climbing ceremonies can take many forms, including the challenge of retrieving bags of goods at the top, standing on top, or several young males leaping off with ropes attached to unwind while they spiral down (Beekman 2003). Importantly, the practice may have originated in Mesoamerica during precolumbian times (Beekman 2003) and, although speculative, it could have been shared with the people at Pueblo Bonito. Connections between these cultures are apparent in the sharing of ceremonial items and practices during the Chacoan Phenomenon (Crown and Hurst 2009; Watson et al. 2015).
Finally, JPB-99 could have served far more mundane purposes. It might have been a log staged for construction of a new room or to replace a damaged beam in an existing room. It could have been a bench or intended for fuelwood. A photograph of the firebox noted above from the LTRR files (LTRR-31B-14) shows a large burned portion of a stump, complete with prominent root stubs, that is reminiscent of JPB-99. This suggests that such logs could have been brought into Pueblo Bonito to meet fuel demands in an arid and cold canyon.

\section{Conclusions}

The Plaza Tree of Pueblo Bonito is an enduring mystery of archaeology in the U.S. Southwest. Its location, size, and age have given legendary status to a decayed and buried log. The tree is currently associated with the chosen location, design, and construction of Pueblo Bonito as well as the paleoecology of Chaco Canyon. We examined three independent lines of evidencedocuments, strontium isotopes, and tree-ring growth patterns- to test whether the tree grew in Pueblo Bonito, Chaco Canyon, or a distant forested mountain range. The findings of each line of evidence are convergent and corroborate one another, and so we present a revised origin narrative.

The Plaza Tree of Pueblo Bonito did not grow in Pueblo Bonito or Chaco Canyon. It germinated in the Chuska Mountains over $50 \mathrm{~km}$ to the west of Chaco Canyon sometime before AD 732. It lived in the mountains for over 250 years. Its outermost heartwood ring dates to the end of the tenth century. We will never know exactly when it died because its outer sapwood rings were lost to decay, but we estimate that it was living until the early AD 1100s. Following its death, by either natural causes or cutting (we cannot be sure), it was transported to Pueblo Bonito in the twelfth century, where it was either abandoned or employed for some purpose (possibly as a standing pole). It could have toppled or been left standing to eventually collapse onto the plaza. Finally, it was buried by windblown sand over the centuries.

That JPB-99 was obtained from a distant landscape somewhat alters our perception of the 
history of Pueblo Bonito. Contrary to past beliefs based on Judd's narrative, the tree was not a relic of an extant forest in Chaco Canyon. The tree could not have been a marker for siting the location of Pueblo Bonito nor in determining its orientation, configuration, or layout. It cannot be a symbol of the "birth" or "life" of the pueblo, although it could have been used as a gnomon for marking the timing or locations of structures, features, and events in the early twelfth century. If a marker of anything, the Plaza Tree of Pueblo Bonito reflects the final florescence or decline of Pueblo Bonito rather than its beginning.

Acknowledgments. We would like to thank Karen R. Adams, Rex K. Adams, Julio Betancourt, Dabney Ford, and Chip Wills for their thought-provoking discussions. Thanks also to Claudio Latorre for translating the abstract into Spanish. We were funded by the National Park Service Desert Southwest CESU (award \#UAZDS-381) and the Western National Parks Association (grant 13-02), with additional assistance from National Science Foundation award 1114898 to TWS and Environmental Protection Agency STAR Fellowship FP-91769601-1 to CHG. This project was conducted with the permission of the University of Arizona Laboratory of Tree-Ring Research, Chaco Culture National Historical Park (CHCU 11-05), and the Navajo Nation (FY-12-118; C14028).

Data Availability Statement. The documentary records we present are maintained in the archives of the Laboratory of Tree-Ring Research at the University of Arizona. Strontium isotope data used in this study are provided in Table 1 and can be obtained from previously published studies cited herein. The regional network of tree-ring chronologies is available from Guiterman and others (2016:online supplemental materials). Raw tree-ring measurements for JPB-99 and the living Chaco trees will be made available upon request.

\section{Notes}

1. It is possible that samples of the trees and logs photographed and described by Judd and Douglass are in the LTRR collections. In a letter to Douglass (August 5, 1933), Judd inquires about the dating of "two pine logs we found in the ravine four miles southeast of Bonito." In Douglass's response (August 17, 1933), he states, "I don't know why the two pine logs that were buried in soil at that place did not give a date." We found two hand-cut samples of ponderosa pine in a box of specimens from living trees in Chaco Canyon labeled DPB for Douglass Pueblo Bonito-a moniker that is rarely used. Their tree-ring patterns are extremely suppressed and cannot be dated. Because Douglass never identified the sample numbers in his letter, we cannot confirm that these are the logs photographed by Judd, so we do not know for sure where they were obtained. Although we feel that they probably are the same logs, we made the conservative decision not to use them in our analysis.
2. These undatable trees include a lone pine on top of the mesa above Casa Rinconada, just south of Pueblo Bonito (Douglass 1935:40) and two specimens that Douglass labeled "rock pines" that we believe may be from the two logs he photographed in the rocks above Casa Rinconada and along the edges of Weritos Rincon (Judd 1954; see also note 1).

3. In fact, the tree would not have been encompassed by the courtyard until the late eleventh century, following Stage III construction (Stein et al. 2003), but the ring series of JPB-99 ends after AD 981. During this construction phase, the plaza floor was raised by $2 \mathrm{~m}$ with fill, which would have killed the tree. As Wills (2012) notes, for the base of the tree to sit on the last occupation surface, it would have had to be exhumed and left on the new post-Phase III plaza floor.

\section{References Cited}

Ashmore, Wendy

2007 Building Social History at Pueblo Bonito: Footnotes to a Biography of Place. In The Architecture of Chaco Canyon, New Mexico, edited by Stephen Lekson, pp. 179-198. University of Utah Press, Salt Lake City.

Bannister, Bryant

1977 Tree-Ring Dating of the Archaeological Sites in the Chaco Canyon Region, New Mexico. 3rd ed. Technical Series Vol. 6, Pt. 2. Southwest Parks and Monuments Association, Globe, Arizona.

Beekman, Christopher S.

2003 Agricultural Pole Rituals and Rulership in Late Formative Central Jalisco. Ancient Mesoamerica 14:299-318.

Betancourt, Julio L., Jeffrey S. Dean, and Herbert M. Hull 1986 Prehistoric Long-Distance Transport of Construction Beams, Chaco Canyon, New Mexico. American Antiquity 51:370-375.

Betancourt, Julio L., and Thomas R. Van Devender

1981 Holocene Vegetation in Chaco Canyon, New Mexico. Science 214:656-658.

Bridge, Martin

2012 Locating the Origins of Wood Resources: A Review of Dendroprovenancing. Journal of Archaeological Science 39:2828-2834.

Creasman, Pearce Paul, Christopher H. Baisan, and Christopher H. Guiterman

2015 Dendrochronological Evaluation of Ship Timber from Charlestown Navy Yard (Boston, MA). Dendrochronologia 33:8-15.

Crown, Patricia L., and W. Jeffrey Hurst

2009 Evidence of Cacao Use in the Prehispanic American Southwest. Proceedings of the National Academy of Sciences of the United States of America 106:2110-2113.

Douglass, Andrew Ellicott

1929 The Secret of the Southwest Solved by Talkative Tree Rings. National Geographic 56:736-770.

1935 Dating Pueblo Bonito and Other Ruins of the Southwest. National Geographic Society, Washington, DC.

Drake, Brandon Lee, Wirt H. Wills, Marian I. Hamilton, and Wetherbee Dorshow

2014 Strontium Isotopes and the Reconstruction of the Chaco Regional System: Evaluating Uncertainty with Bayesian Mixing Models. PLoS ONE 9(5):e95580. DOI:10.1371/journal.pone.0105849.

English, Nathan B., Julio L. Betancourt, Jeffrey S. Dean, and Jay Quade 
2001 Strontium Isotopes Reveal Distant Sources of Architectural Timber in Chaco Canyon, New Mexico. Proceedings of the National Academy of Sciences of the United States of America 98:11891-11896.

Fritts, Harold C., David G. Smith, John W. Cardis, and Carl A. Budelsky

1965 Tree-Ring Characteristics along a Vegetation Gradient in Northern Arizona. Ecology 46:393-401.

Glenn, James R.

1982 Register to the Papers of Neil Merton Judd. National Anthroplogical Archives, Smithsonian Institution, Washington, DC.

Guiterman, Christopher H., Thomas W. Swetnam, and Jeffrey S. Dean

2016 Eleventh-Century Shift in Timber Procurement Areas for the Great Houses of Chaco Canyon. Proceedings of the National Academy of Sciences of the United States of America 113:1186-1190.

Hall, Stephen A.

1988 Prehistoric Vegetation and Environment at Chaco Canyon. American Antiquity 53:582-592.

Haury, Emil W.

1962 HH-39: Reflections of a Dramatic Moment in Southwestern Archaeology. Tree-Ring Bulletin 24:11-14.

Judd, Neil M.

1954 The Material Culture of Pueblo Bonito. Smithsonian Institution, Washington, DC.

1964 The Architecture of Pueblo Bonito. Smithsonian Miscellaneous Collections Vol. 147. Smithsonian Institution, Washington, DC.

Kozlowski, T.

1999 Soil Compaction and Growth of Woody Plants. Scandinavian Journal of Forest Research 14:37-41.

Leroy, James A.

1903 The Indian Festival at Taos. Outing, an Illustrated Monthly Magazine of Recreation 43:282-288.

Malotki, Ekkehart, Michael Lomatuway'ma, Lorena Lomatuway'ma, and Sidney Namingha

2002 Hopi Tales of Destruction. University of Nebraska Press, Lincoln.

Martin-Benito, Dario, Neil Pederson, Molly McDonald, Paul Krusic, Javier Martin Fernandez, Brendan Buckley, Kevin J. Anchukaitis, Rosanne D'Arrigo, Laia AndreuHayles, and Edward Cook

2014 Dendrochronological Dating of the World Trade Center Ship, Lower Manhattan, New York City. Tree-Ring Research 70:65-77.

Nash, Stephen E.

1997 A Cutting-Date Estimation Technique for Ponderosa Pine and Douglas Fir Wood Specimens. American Antiquity 62:260-272.

1999 Time, Trees, and Prehistory: Tree-Ring Dating and the Development of North American Archaeology, 1914-1950. University of Utah Press, Salt Lake City.

Parsons, Elsie C

1933 Some Aztec and Pueblo Parallels. American Anthropologist 35:611-631.
Parsons, Elsie C., and Ralph L. Beals

1934 The Sacred Clowns of the Pueblo and Mayo-Yaqui Indians. American Anthropologist 36:491-514.

Reynolds, Amanda C., Julio L. Betancourt, Jay Quade, P. Jonathan Patchett, Jeffrey S. Dean, and John Stein

$2005{ }^{87} \mathrm{Sr} /{ }^{86} \mathrm{Sr}$ Sourcing of Ponderosa Pine Used in Anasazi Great House Construction at Chaco Canyon, New Mexico. Journal of Archaeological Science 32:10611075.

Roberts, Frank H.

1927 The Ceramic Sequence in the Chaco Canyon, New Mexico, and Its Relation to the Culture of the San Juan Basin. Garland Publishing, New York.

Robinson, William J., Bruce G. Harrill, and Richard L. Warren

1974 Tree-Ring Dates from New Mexico B: ChacoGobernador Area. Laboratory of Tree-Ring Research, University of Arizona, Tucson.

Snygg, John, and Thomas C. Windes

1998 Long, Wide Roads and Great Kiva Roofs. Kiva 64:7-25.

Stein, John, Dabney Ford, and Richard Friedman

2003 Reconstructing Pueblo Bonito. In Pueblo Bonito: Center of the Chacoan World, edited by Jill E. Neitzel, pp. 33-60. Smithsonian Institution, Washington, DC.

Stein, John, Judith Suiter, and Dabney Ford

1997 High Noon in Old Bonito: Sun, Shadow, and the Geometry of the Chaco Complex. In Anasazi Architecture and American Design, edited by Baker Morrow and V. B. Price, pp. 133-148. University of New Mexico Press, Albuquerque.

Stokes, Marvin A., and Terah L. Smiley

1968 An Introduction to Tree-Ring Dating. University of Arizona Press, Tucson.

Watson, Adam S., Stephen Plog, Brendan J. Culleton, Patricia A. Gilman, Steven A. LeBlanc, Peter M. Whiteley, Santiago Claramunt, and Douglas J. Kennett

2015 Early Procurement of Scarlet Macaws and the Emergence of Social Complexity in Chaco Canyon, NM. Proceedings of the National Academy of Sciences of the United States of America 112:8238-8243.

Wills, W. H.

2012 On the Trail of the Lonesome Pine: Archaeological Paradigms and the Chaco "Tree of Life." American Antiquity 77:478-497.

Windes, Thomas C.

2018 Early Puebloan Occupations in the Chaco Region: Excavations and Survey of Basketmaker III and Pueblo I Sites, Chaco Canyon, New Mexico, Vol. I, Parts 1 and 2. National Park Service Reports of the Chaco Center No. 13. Arizona State Museum Archaeological Series 214. University of Arizona, Tucson.

Submitted November 7, 2019; Revised January 15, 2020; Accepted January 15, 2020 